\title{
Analisis Kemampuan Spasial Matematis Siswa dalam Menyelesaikan Soal-Soal Pythagoras
}

\author{
Rika Dwi Cahyani ${ }^{1 *}$, Yanti Mulyanti ${ }^{2}$, \& Novi Andri Nurcahyono \\ 1, 2,3 Universitas Muhammadiyah Sukabumi, Sukabumi, Indonesia
}

\section{INFO ARTICLES}

Article History:

Received: 22-12-2020

Revised: 25-12-2020

Approved: 25-12-2020

Publish Online: 25-12-2020

\section{Key Words:}

Mathematical Spatial Ability; Pythagoras;

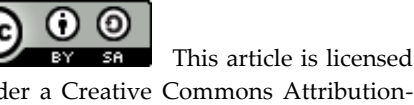
under a Creative Commons AttributionShareAlike 4.0 International License.

\begin{abstract}
This study aims to describe and analyze the mathematical spatial ability of junior high school students in grade 8 in solving Pythagoras questions. This type of research is case study research with qualitative approach and using descriptive qualitative research design. Determination of research subjects using probability sampling and then obtained 1 student from 33 students who were used as research subjects, namely Participant 1 (P1). Research instruments in the form of spatial ability tests that have been validated and meet the rules of instrument writing for research. Data collection in this research is observation, test, interview, and documentation. Data analysis includes data reduction, data presentation, and conclusions. The validity of the data uses triangulation techniques. P1's mathematical spatial ability has fulfilled 5 indicators of spatial ability, with a percentage of spatial ability of $95 \%$.
\end{abstract}

\begin{abstract}
Abstrak: Penelitian ini bertujuan untuk mendeskripsikan dan menganalisis kemampuan spasial matematis siswa SMP kelas 8 dalam menyelesaikan soalsoal Pythagoras. Jenis penelitian ini adalah penelitian studi kasus dengan pendekatan kualitatif dan menggunakan desain penelitian kualitatif deskriptif. Penentuan subjek penelitian menggunakan probability sampling lalu didapat 1 siswa dari 33 siswa yang dijadikan sebagai subyek penelitian yaitu Partisipan 1 (P1). Instrumen penelitian berupa tes kemampuan spasial yang sudah tervalidasi serta memenuhi kaidah penulisan instrumen untuk penelitian. Pengumpulan data dalam penelitian ini yaitu observasi, tes, wawancara, dan dokumentasi. Analisis data meliputi reduksi data, penyajian data, dan kesimpulan. Keabsahan data menggunakan triangulasi teknik. Kemampuan spasial matematis P1 telah memenuhi 5 indikator kemampuan spasial, dengan persentase kemampuan spasial $95 \%$.
\end{abstract}

Correspondence Address: Jln. R. Syamsudin, S.H. No. 50, Kota Sukabumi, Kode Pos 43113, Negara Indonesia; $e$ mail: rikadwc@gmail.com

How to Cite (APA $6^{\text {th }}$ Style): Cahyani, R.D. Mulyanti, Y., \& Nurcahyono, N.A. (2020). Analisis Kemampuan Spasial Matematis Siswa dalam Menyelesaikan Soal-Soal Pythagoras. JKPM (Jurnal Kajian Pendidikan Matematika), 6(1): $149-156$.

Copyright: 2020 Rika Dwi Cahyani, Yanti Mulyanti, Novi Andri Nurcahyono

Competing Interests Disclosures: The authors declare that they have no significant competing financial, professional or personal interests that might have influenced the performance or presentation of the work described in this manuscript. 


\section{PENDAHULUAN}

Matematika menjadi salah satu mata pelajaran wajib di setiap jenjang pendidikan di Indonesia, mulai dari Sekolah Dasar (SD), bahkan sampai Perguruan Tinggi. Sejalan dengan pendapat Hermawati et al. (2018: 102) bahwa matematika merupakan salah satu ilmu dasar yang wajib diajarkan pada semua jenjang pendidikan. Tetapi tidak sedikit siswa yang tidak menyukai dan menguasai pelajaran matematika. Karena matematika identik dengan kata sulit. Sebagai contoh, Siregar (2017: 227) menunjukkan bahwa $35 \%$ siswa menyatakan mata pelajaran matematika adalah mata pelajaran yang mudah dan menyenangkan, 45\% siswa menyatakan pelajaran matematika adalah mata pelajaran yang cukup sulit, dan $20 \%$ siswa lainnya menyatakan pelajaran matematika adalah mata pelajaran yang sulit. Hal ini juga diperkuat oleh hasil survei yang dilakukan oleh Program for Student Assesment (PISA) dalam Sari (2018 : 1) yang akan disajikan dalam Tabel 1.

Tabel 1. Skor Hasil Survei Pisa pada Pelajaran Matematika

\begin{tabular}{ccc}
\hline Tahun & Peringkat & Skor \\
\hline 2000 & 39 dari 41 negara & 367 \\
2003 & 38 dari 40 negara & 360 \\
2006 & 50 dari 57 negara & 397 \\
2009 & 61 dari 65 negara & 371 \\
2012 & 64 dari 65 negara & 375 \\
2015 & 69 dari 76 negara & 386 \\
2018 & 72 dari 79 negara & 379 \\
\hline
\end{tabular}

Berdasarkan Tabel 1., rendahnya peringkat Indonesia ini semakin memperkuat bahwa siswa di Indonesia masih merasa kesulitan dalam mempelajari matematika. Salah satu faktor yang menyebabkan matematika menjadi pelajaran yang sulit adalah sifatnya yang abstrak. Seperti yang telah dikemukakan Kurniawan \& Marliani (2014: 89) bahwa matematika merupakan ilmu yang abstrak dan sulit dibayangkan. Salah satu penyebab siswa kesulitan dalam mengimajinasikan matematika menurut Nurcahyono (2019) adalah belum adanya penelitian yang membahas imajinasi matematis di sekolah sehingga guru tidak mempunyai data dan rekomendasi untuk mengembangkan pembelajaran yang dapat mengakomodasi perkembangan imajinasi siswa, juga sumber daya untuk belajar bagaimana mengadaptasi otak kanan siswa dalam menyelesaikan masalah matematika di Indonesia masih terbatas. Kemampuan berimajinasi siswa termasuk ke dalam kemampuan spasial, oleh karena itu kemampuan spasial sangat penting dalam proses pembelajaran matematika yang abstrak. Jelatu et al. (2018: 50) menyatakan bahwa siswa berkemampuan spasial mampu mengenal, mengelola, dan menciptakan gambar, betuk, dan ruang tiga dimensi. Namun pada kenyataannya masih ada siswa yang kesulitan dalam mengimajinasikan bentuk matematika. Seperti penelitian yang telah dilakukan oleh Juliani (2018: 10) di MTSN 4 Kota Jambi, yang mengungkapkan bahwa kemampuan spasial di SMPN 4 Kota Jambi masih rendah. Hal ini dibuktikan dari hasil tes kemampuan spasial yang diberikan kepada siswa kelas VIII, dan hasilnya belum mencapai syarat ketuntasan kelas yaitu di bawah $75 \%$.

Pemilihan topik berkaitan dengan Teorema Pythagoras karena tidak bisa dipungkiri bahwa siswa masih belum memahami dengan baik terkait materi ini. Hal ini mengacu pada penelitian Mulyanti, Yani, \& Amelia (2018) kurangnya penguasaan konsep atau prasyarat mengenai Teorema Pythagoras. Rohati, Winarni, \& Osviarni (2012) menjelaskan, penyelesaian dengan dasar Teorema Pythagoras untuk menentukan panjang sisi-sisi segitiga siku-siku. Dalam kaitannya dalam memecahkan masalah pada 
bangun datar, maka kemampuan spasial menjadi penting untuk mengimajinasikan masalah dengan mengaitkan konsep dalam Teorema Pythagoras.

\section{METODE}

Jenis penelitian yang akan digunakan adalah penelitian studi kasus untuk menggali informasi tentang kemampuan spasial matematis siswa SMPN 1 Cisaat dalam menyelesaikan soal-soal Pythagoras yang akhirnya bisa dipelajari atau ditarik dari sebuah kasus, baik kasus tunggal maupun jamak (Rahardjo, 2017: 13). Pendekatan yang digunakan dalam penelitian ini adalah penelitian kualitatif untuk mendapatkan data yang mendalam dan suatu data yang mengandung makna dari permasalahan yang belum jelas serta kompleks (Sugiyono, 2016: 9). Penelitian dilaksanakan di SMPN 1 Cisaat pada tahun ajaran 2019/2020. Subjek dalam penelitian ini adalah siswa siswa kelas VIII A yang berjumlah 33 siswa, dan diambil 1 orang siswa sebagai subyek. Pengumpulan data dilakukan melalui tes kemampuan spasial yang telah memenuhi kaidah penggunaan instrumen untuk penelitian dan sudah tervalidasi. Kemudian peneliti akan menganalisis hasil jawaban siswa dan melakukan wawancra mendalam dengan siswa, juga dokumentasi yang berhubungan dengan penelitian sebagai data pendukung.

Kriteria penskoran yang akan digunakan dalam penelitian ini adalah rubrik penskoran menurut Lestari \& Yudhanegara (2015: 182), disajikan dalam Tabel 2.

Tabel 2. Rubrik Penskoran

\begin{tabular}{cccc}
\hline \multirow{2}{*}{$\begin{array}{c}\text { So. } \\
\text { Soal }\end{array}$} & $\begin{array}{c}\text { Indikator Kemampuan Spasial } \\
\text { Matematis yang Diukur }\end{array}$ & \multicolumn{3}{c}{ Klasifikasi Jawaban Siswa } \\
Untuk No. 1 s.d. 5
\end{tabular}

\section{HASIL}

Peneliti melakukan tes kemampuan spasial matematis yang sudah tervalidasi dan telah memenuhi kaidah penulisan instrumen yang baik untuk penelitian, kepada subyek penelitian. Dapat dilihat mana saja siswa yang memenuhi indikator kemampuan spasial sebagaimana disajikan dalam Tabel 3. 
Tabel 3. Skor Hasil Jawaban Siswa

\begin{tabular}{llcc}
\hline No & \multicolumn{1}{c}{ Indikator Kemampuan Spasial Matematis } & Cek & Skor \\
\hline 1 & $\begin{array}{l}\text { Aspek : Spatial Orientation } \\
\text { Indikator : Menentukan penampilan objek dari } \\
\text { perspektif yang berbeda }\end{array}$ & $\sqrt{ }$ & \\
2 & $\begin{array}{l}\text { Aspek : Spatial Relation } \\
\text { Indikator : Menentukan hubungan suatu objek } \\
\text { dengan objek lainnya }\end{array}$ & $\sqrt{ }$ & \\
3 & $\begin{array}{l}\text { Aspek : Spatial Visualization } \\
\text { Indikator: Menentukan komposisi suatu objek } \\
\text { setelah dimanipulasi posisi dan bentuknya } \\
4\end{array}$ & $\sqrt{ }$ & 4 \\
& $\begin{array}{l}\text { Aspek : Spatial Visualization } \\
\text { Indikator: Mengubah suatu objek ke dalam bentuk }\end{array}$ & $\sqrt{ }$ & 4 \\
5 & $\begin{array}{l}\text { Aspek: Spatial Relation } \\
\text { Indikator : Merotasikan posisi suatu objek }\end{array}$ & $\sqrt{ }$ & 3 \\
\hline
\end{tabular}

Data dalam Tabel 3. Menunjukkan bahwa siswa tidak mengalami masalah dalam ketiga aspek kemampuan spasial, yaitu: spatial orientation, spatial relation, spatial visualization, dan spatial visualization. Data awal ini perlu dianalisis Kembali merujuk dari hasil jawaban tertulis siswa, maupun perlu ditindaklanjuti dengan melakukan wawancara. Terlebih pada aspek spasial relation, skor yang diperoleh oleh siswa tidak pada skor maksimal. Hal ini juga perlu dianalisa dalam kaitannya jawaban tertulis subyek, maupun ditindaklanjuti melalui wawancara dengan siswa (subyek penelitian). Selanjutnya siswa (subyek) dalam penelitian ini diberi penamaan sebagai P1 (Partisipan 1) Hasil jawaban tertulis siswa disajikan dalam Gambar 1., Gambar 2., Gambar 3., dan Gambar 4.

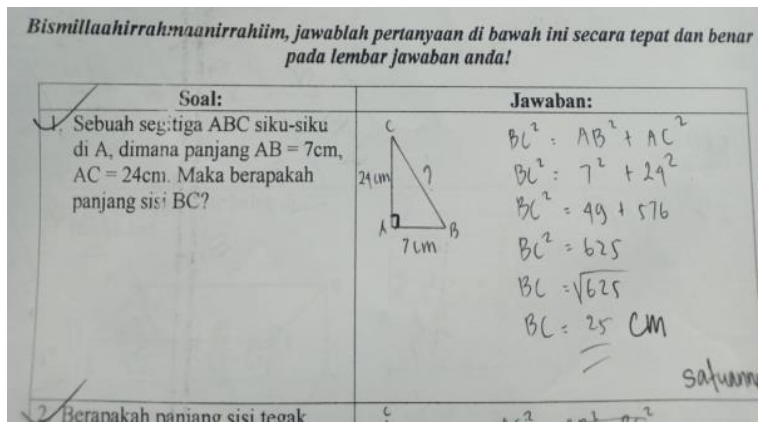

\section{Gambar 1. Soal dan Jawaban Tertulis P1 pada Nomor 1}

Berdasarkan Gambar 1., terlihat bahwa P1 (Partisipan 1) sudah mengerti dan paham apa maksud dari soal yang diberikan. P1 bisa menentukan di mana letak titik sudut siku-siku pada nomor 1. P1 dapat menentukan objek segitiga $\mathrm{ABC}$ dari suatu narasi dalam soal. Hal demikian menunjukkan P1 menampilkan objek dari perspektif yang berbeda.

Selanjutnya, untuk mengetahui P1 dari segi aspek spatial relation diberikan soal nomor 2. Indikator yang diberikan, menentukan hubungan suatu objek dengan objek lainnya. Konteks soal dengan memberikan indikator hubungan antar sisi dalam segitiga siku-siku. 


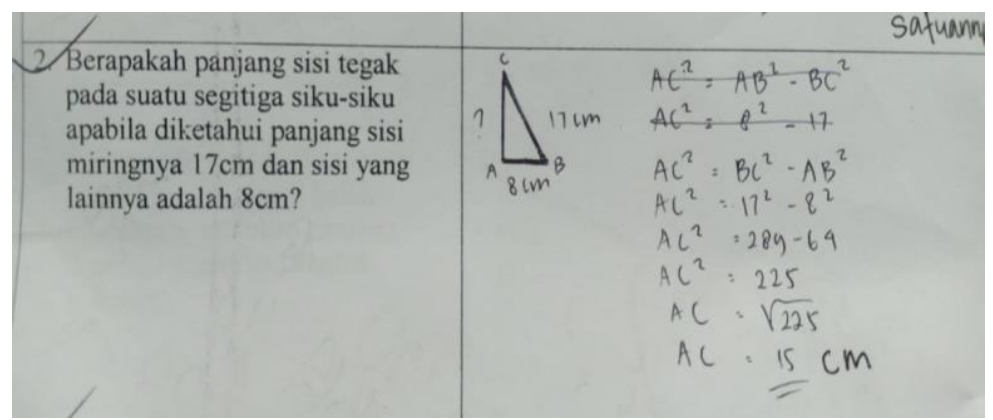

Gambar 2. Soal dan Jawaban Tertulis P1 pada Nomor 2

Informasi yang dapat diperoleh dari Gambar 2., P1 sudah bisa memahami dan bisa mengimajinasikan sekaligus menggambarkan bentuk segitiga siku-siku dari soal nomor 2. Proses imajinasi dilakukan dengan ilustrasi segitiga berdasarkan penamaan segitiga ABC. Dengan demikian nama-nama sisi yang sebelumnya adalah sisi tegak, sisi miring dan sisi lainnya, diinterpretasikan/direduksi menjadi sisi $\mathrm{AB}, \mathrm{AC}$, dan $\mathrm{BC}$.

Aspek spatial visualization berdasarkan indikator menentukan komposisi suatu objek setelah dimanipulasi posisi dan bentuknya, ditunjukkan P1 dalam menuliskan jawabannya dan tersaji dalam Gambar 3.

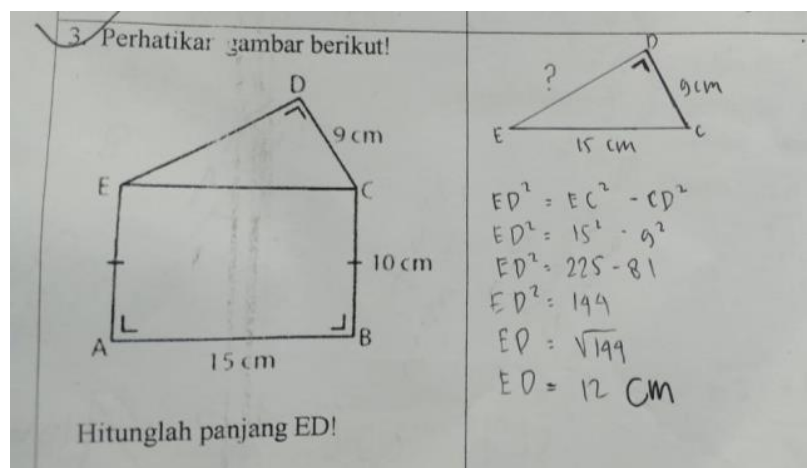

\section{Gambar 3. Soal dan Jawaban Tertulis P1 pada Nomor 3}

P1 mampu mengidentifikasi mana sisi miring, sisi tegak lurus, dan sisi alas pada suatu segitiga yang sudah dimanipulasi bentuknya di soal nomor 3, terlihat dalam Gambar 3. P1 dapat menentukan komposisi suatu objek setelah dimanipulasi posisi dan bentuknya, P1 tidak mengalami kerancuan saat mendefinisikan ulang penamaan sisi miring dalam segitiga siku-siku.

Gambar 4. menyajikan aspek spatial visualization, hasil dari jawaban tertulis P1 dengan indikator mengubah suatu objek kedalam bentuk yang berbeda.

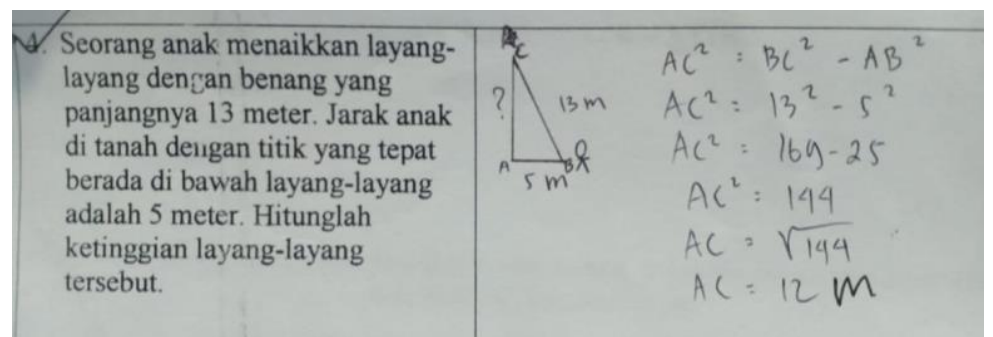

Gambar 4. Soal dan Jawaban Tertulis P1 pada Nomor 4

Gambar 4. menunjukkan P1 mampu membayangkan dan menggambarkan soal cerita yang kemudian P1 mengibaratkannya seperti suatu segitiga pada soal nomor 4. 


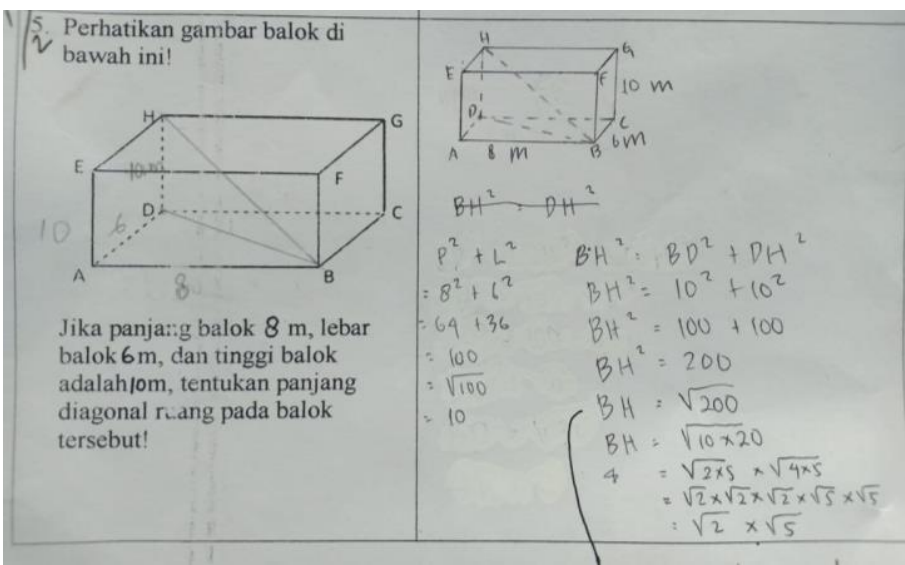

Gambar 5. Soal dan Jawaban Tertulis P1 pada Nomor 5

Analisis dari Gambar 5., menunjukkan P1 sudah dapat memenuhi aspek spatial relation, dengan indikator merotasikan posisi suatu objek. Akan tetapi, P1 menemukan kesulitannya di soal nomor 5 ini. Berdasarkan indikator dan rubrik penskoran sebelumnya, terlihat bahwa P1 sudah setengahnya mampu menyelesaikan soal nomor 5 tersebut. Oleh karena itu peneliti melakukan wawancara untuk mengetahui faktor yang menyebabkan P1 kesulitan di nomor 5.

Berikut hasil wawancara P1

$P$ : “Apakah kamu merasa soal no. 5 adalah soal yang sulit?”

P1 : "Ya, cukup sulit Bu."

$P$ : “Apa yang membuatmu kesulitan di soal nomor 5 ini?"

P1 : "Aku gak tau berapa akar dari 200, mentok di situ."

$P$ : "Kalau untuk mencari diagonal ruang, coba bagaimana caranya?"

P1 : "Dibikin segitiga baru Bu, segitiga DHB. HB di sini itu diagonal ruangnya atau sisi miring, DH itu tingginya, dan karena alasnya belum diketahui makanya dicari dulu pakai Pythagoras di segitiga ABD buat cari alas atau panjang BD."

$P$ : "Baik, kenapa kamu pilih segitiga DHB untuk mencari diagonal ruang? Apa masih bisa pakai segitiga yang lain?”

P1 : "Bisa Bu, yang penting ada salah satu sisi yang jadi diagonal ruang."

$P$ : "Boleh ditunjukkan contoh segitiganya yang lain?"

$P 1$ : "Boleh Bu, contoh lain segitiga ACG."

$P$ : "Kalau AGF bisa?"

P1 :"Bisa juga Bu AGF"

Dari uraian di atas, secara keseluruhan P1 sudah memenuhi semua indikator kemampuan spasial. Sehingga untuk menghitung persentase kemampuan spasial matematis yang dimiliki siswa P1 menggunakan rumus, $\frac{\text { Jumlah Skor Siswa }}{\text { Jumlah Skor Keseluruhan }} \times 100 \%$, didapat persentase kemampuan spasial matematis siswa, $\mathrm{P} 1=\frac{19}{20} \times 100 \%=95 \%$. Walaupun demikian, hasil ini menunjukkan bahwa dalam aspek spatial relation dengan indikator merotasikan posisi suatu objek, P1 (subyek yang diambil) mengalami masalah, dengan indikator tidak memenuhi skor maksimal. Temuan dalam wancara, menunjukkan permasalahan terletak dari operasi hitungnya saja, untuk aspek spatial relation subyek sudah mampu menarik hubungan dengan konsep-konsep yang sudah dipelajari. 


\section{PEMBAHASAN}

Kemampuan untuk menemukan kembali teorema yang ada menjadi bekal yang baik dalam proses pembelajaran siswa. Berdasarkan penelitian Mulyatna (2019), dapat diambil pemahaman bahwa pelibatan siswa dalam mengonstruksi pengetahuan baru, akan menjadikan konsep dapat diingat dalam jangka waktu yang lebih lama. Berbeda halnya jika pemahaman konsep hanya diperoleh melalui hafalan.

Seperti halnya dalam penelitian Ulandari, dkk. (2019), siswa diminta untuk menemukan Teorema Pythagoras dengan media pembelajaran yang disediakan. Pemodelan terkait konsep dalam Teorema Pythagoras menggunakan karton. Siswa diberikan petunjuk teknis saja, untuk ide dan gagasan bagaimana menemukan konsep-konsep dalam Teorema Pythagoras diserahkan kepada siswa. Proses pembelajaran yang demikian akan menguatkan kemampuan spasial siswa. Murniasih (2016) juga masih mengangkat topik penelitian dalam hal media manipulatif dalam mengonstruksi konsep-konsep dalam Teorema Pythagoras.

Pada penyajian penelitian ini, kemampuan spasial yang dimiliki subyek berada pada persentase $95 \%$, dengan kesulitan yang dihadapi pada aspek spasial relation, sedangkan indikatornya merotasikan posisi suatu objek. Hal ini dapat menjadi indikasi awal, bahwa dalam pembelajaran perlu untuk melakukan eksprolari terhadap konsep. Maksudnya adalah permasalahan terkait Teorema Pythagoras ini perlu disajikan dalam bentuk yang eksplisif, jadi tidak tersaji langsung. Siswa perlu melakukan interpretasi, siswa perlu melakukan analisis. Dengan demikian, kemampuan siswa dapat teruji dengan baik.

\section{SIMPULAN}

Kemampuan spasial P1 telah memenuhi 5 aspek dengan masing-masing indikatornya, dengan mendapatkan persentase skor sebesar 95\%, meskipun P1 menemukan kesulitan saat pengerjaan pada indicator merotasikan posisi suatu objek, yaitu pada aspek spasial relation. Kesulitan yang dihadapi P1 bukan dari kemampuan spasialnya melainkan P1 sedikit kesulitan dalam mengoperasikan hitungan.

\section{DAFTAR RUJUKAN}

Hermawati, H., Nurcahyono, N. A., \& Setiani, A. (2018). Proses Pelaksanaan Remedial Teaching terhadap Ketuntasan Belajar Matematika Peserta Didik. Jurnal LP3M, 4(2), 102.

Jelatu, S. et al. (2018). Relasi antara Visualisasi Spasial dan Orientasi Spasial terhadap Pemahaman Konsep Geometri Ruang. Journal of Songke Math, 1(1), 50.

Juliani, D. (2018). Analisis Kemampuan Spasial Siswa Kestetik dalam Pemecahan Masalah Matematika pada Materi Bangun Ruang Kelas VIII MTSN 4 Kota Jambi. Skripsi: Universitas Jambi.

Kurniawan, A.T., \& Marliani, L. (2014). Pembelajaran Matematika Konsep Aljabar terhadap Siswa Kelas VII SLTP Melalui Website Interaktif. Jurnal $\delta$ E L T $\Delta, 2(1), 89$.

Lestari, K. E., \& Yudhanegara, M. R. (2015). Penelitian Pendidikan Matematika. Bandung: P.T. Refika Aditama.

Mulyanti, N. R., Yani, N., \& Amelia, R. (2018). Analisis Kesulitan Siswa dalam Pemecahan Masalah Matematik Siswa SMP pada Materi Teorema Phytagoras. JPMI-Jurnal Pembelajaran Matematika Inovatif, 1 (3), 415-426. http://dx.doi.org/10.22460/jpmi.v1i3.p415-426

Mulyatna, F. (2019). Proses Pembentukan Konsep dalam Menemukan Kembali Teorema Pythagoras dan Miskonsepsi yang Terjadi dengan Pendekatan Pendidikan Matematika Realistik Indonesia 
(PMRI). ARITHMETIC: Academic Journal of Math, 1(1), 1-22. https://doi.org/http://dx.doi.org/10.29240/ja.v1i1.762

Murniasih, T.R. (2016). Penggunaan Media Manipulatif untuk Meningkatkan Pemahaman Konsep Siswa Pada Teorema Pythagoras. Prosiding Seminar Nasional Pendidikan Matematika Universitas Negeri Malang. Malang: CV. Bintang Sejahtera.

Nurcahyono, N. A., Suryadi, D., \& Prabawanto, S. (2019). Analysis of Students' Mathematical Imagination Ability in Solving Problems. Journal of Physics, 11796. file:///F:/rika/up/jurnal\%20artikel/Jurnal\%20pa\%20novi,\%20imajinasi\%20matematis.pdf

Rahardjo, M. (2017). Studi Kasus dalam Penelitian Kualitatif: Konsep dan Prosedurnya. Program Pascasarjana Universitas Islam Negeri Maulana Malik Ibrahim Malang: Tidak diterbitkan.

Rohati, R., Winarni, S., \& Osviarni, R. (2012). Pembelajaran Teorema Phytagoras dengan Menggunakan Strategi Relating, Experiencing, Applying, Cooperating, Transferring (React) pada Siswa di SMP Negeri 16 Kota Jambi. Edumatica: Jurnal Pendidikan Matematika, 2(02). https://doi.org/10.22437/edumatica.v2i02.842

Sari, D. P. (2018). Analisis Kemampuan Spasial dan Self-Efficacy Siswa pada Pembelajaran Kooperatif Tipe Jigsaw di SMAS Muhammadiyah 8 Kisaran. Tesis: Universitas Negeri Medan

Siregar, N.R. (2017). Persepsi Siswa pada Pelajaran Matematika: Studi Pendahuluan pada Siswa yang Menyenangi Game. Jurnal UNISSULA. 227.

Sugiyono. (2016). Metode Penelitian Kuantitatif, Kualitatif, dan R\&D. Bandung: Alfabeta, CV.

Ulandari, N., Putri, R., Ningsih, F., \& Putra, A. (2019). Efektivitas Model Pembelajaran Inquiry terhadap Kemampuan Berpikir Kreatif Siswa pada Materi Teorema Pythagoras. Jurnal Cendekia: Jurnal Pendidikan Matematika, 3(2), 227-237. https://doi.org/10.31004/cendekia.v3i2.99 